\title{
突発性難聴の予後判定
}

一平衡機能検查, 蝸電図法を指標とする観察—

岩永 迪孝* ・山本 悦生**

Prognostic Diagnosis of Sudden Deafness

- Based on the Examination of Equilibrium

Test and Electrocochleography-

\author{
Michitaka Iwanaga \\ (Kitano Hospital) \\ Etsuo Yamamoto \\ (Kyoto University)
}

Forty-three patients with sudden deafness were examined by equilibrium tests and electrocochleography during the early stage of the onset (within two weeks). We estimated the role of the tests about the prognosis of sudden deafness. The results were as follows.

1) In complete recovery, the wave forms of AP response were high amplitude and the -SP appeared. The latency of AP response was almost within normal limit (1.35 $\sim 1.75 \mathrm{msec}$ ). Examined by equilibrium tests there were no abnormal findings in all patients but one.

2) In remarkable improvement, the wave forms of AP response were low amplitude and those of the -SP were same. In a large number of the cases latency of the AP delayed at $85 \mathrm{dBHL}(>2.0 \mathrm{msec})$. In thirteen of sixteen cases the equilibrium tests revealed abnormal findings.

3) In slight improvement and no change, there were some cases of no response of AP and -SP. Examined by equilibrium tests it seemed to indicate that the neural regions were impaired.

As above-mentioned it was concluded that the electrocochleography and equilibrium tests were very helpful in estimating the prognosis of sudden deafness during the early stage of the onset.

$$
\text { I は じめに }
$$

突発性難恥は，回復を期海しうる数少い感音性難聴の一つであり，早期に適切な治療を行えば予 後良好といわれている。しかし，早期に治療を開始してあ回復しない症例もある，従って，初診時

*田附興風会研究所北野病院耳鼻咽喉科 (部長 : 森弘博士)

**京都大学医学部耳鼻咽喉科学教室（主任：桧学教授） 
あるいは発症後間もない時期に予後の判定が可能か否かは臨床_上重要な問題である.

今回, 突発性難聴症例に平衡機能検查, 蝸電図検査を行い, その成績が突発性難聴の予後を判定 しうるか否かを検討したので報告する。

\section{II 対}

検査の対象は，1976年 5 月より1980年 2 月ま での間に食敷中央病院耳鼻科を受㟝し，厚生省 班研究診断基準で突発性難恥之診断され, 加療 をうけ，その聴力が固定したと考えられる時期 まで追跡できた43症例である。なお，1978年 9
月以降の 23 症例については蝸電図検査を併せて 施行している.

年令は 12 才り65才の間に分有し, 性別は男 性23名，女性20名である。両側性突発性難恥は ふくまれていない。

\section{III 検 查 方 法}

平衡機能検査は, 多くの例で発症後 1 週間以 内（抢そくとも 2 週間以内）に行った。自営的 に眩暈と蝸牛症状を有するもの, 蝸牛症状のみ のもの, 何れについても検査を行っている. 平 衡機能検査としては, 起立検查, 斜而台検查, 遮眼書字法, 特発又は頭位眼振検查, 足踏検 查, 温度眼振検查, 视運動性眼振検烃, 視標追 跡眼運動検査を行った.

蝸電図の测定は次のように行った。すなわ ち, シールドした防音室内で検查を行い, 鼓膜 輪部に銀ボール電極を装着し，不関電極は同側 の耳垂に，接地電極は前額正中部に装着した。 刺激音は Dana 505A を用い, 主として sine 半波を使用した。 $500 \mathrm{~Hz}, 1 \mathrm{KHz}, 2 \mathrm{KHz}, 4 \mathrm{KHz}$

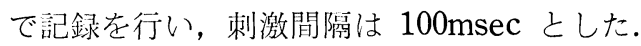
$\mathrm{S} \mathrm{P}$ を分離記録するには，刺激頻度の増加によ る A Pの順応現象を利用した。刺激は closed method により, T D H -49 の受話器を用い

\section{IV 検 查 成 績}

I 了平衡機能検査成績 : 聴力回復との関連に おいて

平衡機能検查成績と聴力の回復程度の相関を 調查したとてろ表 1 の成績が得られた。すなお ち, 治癒 13 例のうち, 温度眼振検查で難聴側に C P 型を示した 1 例を除き，12例が平衡機能検 査で異常を認めなかった。著明回復16例のうち 13例では, 何らかの項目の平衡機能検查で異常
た。健側耳には 40〜 50dB の White Noise で Masking を行った。加算回数は500回ないしは 1000 回行い, 解析侍間は $10 \mathrm{msec} と し, A t a c$ 350 によりデータ処理を行い, 反応波形を $\mathrm{X}$ Yレコーダーに記録した。

な拉, 恥力变動の判定は, 厚生省特定疾患突 発性難呫研究班で決められた，以下に記す判定 基準に従った。

治癒: (1) $0.25,0.5,1,2,4 \mathrm{KHz}$ が $20 \mathrm{~dB}$ 以 内にもどったもの

(2)健側恥力が安定と考えられれば患側がそれ と同程度まで改善したとき

著明回復：上記 5 周波数の算術平均值が 30 $\mathrm{dB}$ 以上改善したとき

回復：上記 5 周波数の算術平均值が $10 \sim 30$ $\mathrm{dB}$ 改善したとき

不変 : 同じくの值が $\pm 10 \mathrm{~dB}$ 以内の変化

所見を認めた。また，回復例では11例中10例に， 不変例では 3 例全例に, 平衡機能に関して異常 所見を認めた。すなわち，聴力の回復状態と平 衡機能検査成績の相関をみると, 平衡機能検査 で異常所見を認めない16例中12例では聴力は治 癒の状態にまで改善している。乙れに反し，平 衡機能検查で異常所見を認めた27例中, 治癒の 状態にまで聴力の改善した症例はわずかに 1 例 
表 | 聴力回復程度と平衡機能検査成績

\begin{tabular}{|c|c|c|c|}
\hline \multirow{2}{*}{\multicolumn{2}{|c|}{ 治療後聴力 }} & \multicolumn{2}{|c|}{ 平衡機能検查成績 } \\
\hline & & 正 常 & 異 \\
\hline 療 & 13例 & 12例 & 1 例 \\
\hline 著明回復 & 16 & 3 & 13 \\
\hline 回 & 11 & 1 & 10 \\
\hline 変 & 3 & 0 & 3 \\
\hline 計 & 43 & 16 & 27 \\
\hline
\end{tabular}

であり, 残りの 26 例は聴力損失を残し固定する 傾向が認められた。

II蝸電図検查成績: 平衡機能検查成績との 関連において

耳疾患の既往のない正常聴力者10名（19〜45 才）の $85 \mathrm{dBHL}$ における A P の電位は $3.5 \mu \mathrm{v}$ り $10 \mu \mathrm{v}$ の間にあった。 入出力曲線（図 1 ）では A P $\left(\mathrm{N}_{1}\right)$ の電位は, $50 \sim 60 \mathrm{dBHL}$ を境に勾配 の異る $\mathrm{H}$-response curve $と \mathrm{~L}$-response curve

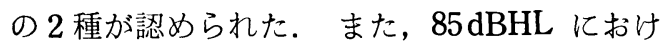
る A P $\left(\mathrm{N}_{1}\right)$ の潜時は最小 $1.35 \mathrm{msec}$, 最大 1.60 msec であった. なお, 振幅は peak to peak で測定し，最大電圧を $\mu \mathrm{v} て ゙$ 表し， maximum \% で表示した。潜時は msec, 刺激音圧は hearing level で表示した。 正常聴力者では蝸電図
上, $2 \mathrm{KHz}, 4 \mathrm{KHz}$ での反応域值は，ほぼ純音オ 一ディオグラムの域值まで求められた.

突発性難聴22例の蝸電図所見は表 2 の如くで あった。この際, 85dBHLにおけるAPの電位

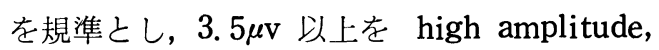
3. $5 \sim 2.0 \mu \mathrm{v}$ を middle amplitude, $2.0 \mu \mathrm{v}$ 以下 を low amplitude と分類した. また, 治癒, 著明回復, 回復の初診時聴力を図 $2 a, b, c, に$ 示した。三者の間に著明な差異は認められなか った。このうち, 治癒は 6 例あり, その蝸電図 所見はすべて AP high amplitudeを示し, 健 側とほぼ同じ程度の振幅であり, 潜時も1.35 1. $75 \mathrm{msec}$ の間にあった。 一 S P は全例に認め たが，鼓室内誘導で認められる Dominant $\mathrm{S} \mathrm{P}^{11}$ は認められなかった. 入出力曲線は Steep Slope ではあったが，3例では L-response curve まで確認しえた。これらの症例での 平衡機能検査成績はすべて正常所見を示した。

著明回復に属する症例は10例あり，乙れらの 症例の蝸電図では, A P $\left(\mathrm{N}_{1}\right)$ は middle 又は low amplitudeを示した。 また， 3 例において は潜時が正常範囲内であったが， 7 例ではA P $\left(\mathrm{N}_{1}\right)$ の潜時は延長し，2.0 $\mathrm{msec}$ 以上にまで達 した.ーS Pは 4 例に認めたが振幅は低かった.

\section{Healthy}

\section{Amplitude}

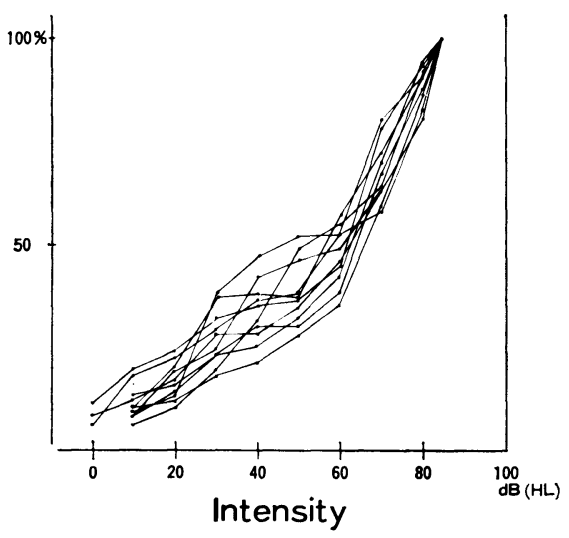

Latency

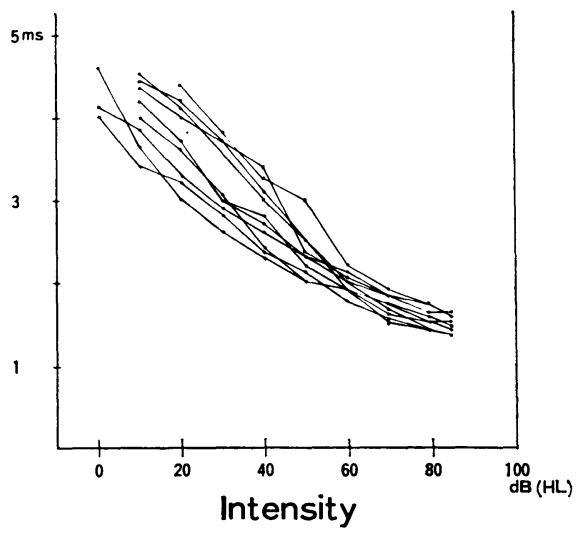

図 I 正常聴力者の入出力曲線 
表 2 蝸電図を施行した突発性難聴症例

a 治痖症例

\begin{tabular}{|c|c|c|c|c|c|c|}
\hline 症 & 例 & 年 令 & 性 & 初唁までの期間 & EcochG施行時期 & EcochG 所見 \\
\hline 1 & & 43 & 金 & 4 & $\begin{array}{c}4 \\
18\end{array}$ & $\begin{array}{l}\text { AP } \\
\text { - } \mathrm{SP} \\
\mathrm{L}-\text { curve } \\
\mathrm{L}: 1.40 \mathrm{msec} \\
\mathrm{L}: 1.42 \mathrm{msec}\end{array}$ \\
\hline 2 & & 59 & $\hat{\delta}$ & 2 & $\begin{array}{c}7 \\
22\end{array}$ & $\begin{array}{l}\text { AP } \quad \text { high } \\
\mathrm{LP}: 1.75 \mathrm{msec} \\
\mathrm{L}: 1.60 \mathrm{msec}\end{array}$ \\
\hline 3 & & 43 & 우 & 3 & $\begin{array}{l}3 \\
7\end{array}$ & $\begin{array}{l}\text { AP } \\
\text { - } \mathrm{SP} \\
\mathrm{L}-\text { curve } \\
\mathrm{L}: 1.35 \mathrm{msec} \\
\mathrm{L}: 1.43 \mathrm{msec}\end{array}$ \\
\hline 4 & & 34 & 우 & 5 & $\begin{array}{r}5 \\
24\end{array}$ & $\begin{array}{l}\text { AP } \quad \text { high } \\
\mathrm{L}: 1.52 \mathrm{msec} \\
\mathrm{L}: 1.50 \mathrm{msec}\end{array}$ \\
\hline 5 & & 53 & 우 & 2 & $\begin{array}{l}2 \\
30\end{array}$ & $\begin{array}{l}\text { AP } \\
\text {-SP high } \\
\mathrm{L}-\text { curve } \\
\mathrm{L}: 1.60 \mathrm{msec} \\
\mathrm{L}: 1.50 \mathrm{msec}\end{array}$ \\
\hline 6 & & 28 & $\hat{0}$ & 2 & $\begin{array}{l}3 \\
21\end{array}$ & $\begin{array}{l}\mathrm{AP} \quad \text { high } \\
\mathrm{L}: 1.53 \mathrm{msec} \\
\mathrm{L}: 1.40 \mathrm{msec}\end{array}$ \\
\hline
\end{tabular}

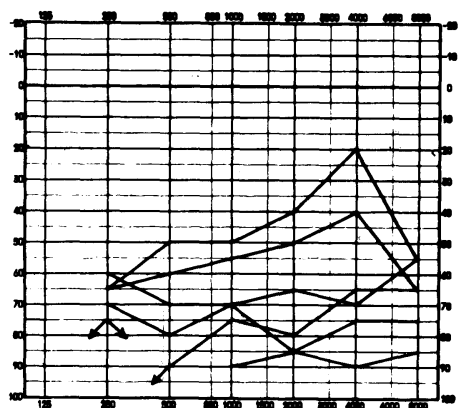

a. 治 癒

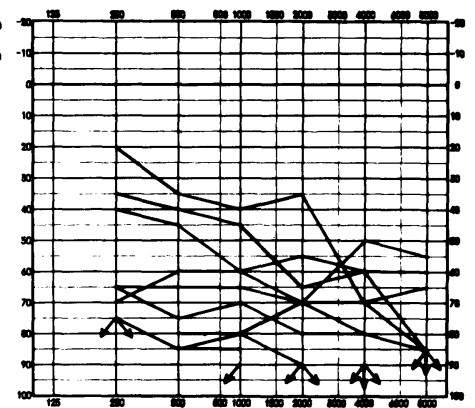

b. 著明回復

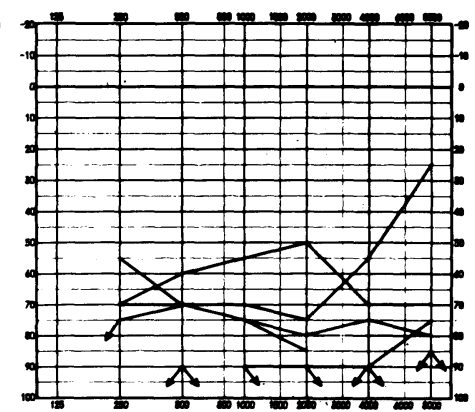

c. 回 復

図 2 治癒例, 著明回復例, 回復例の初診時聴力を示す 
b ）著明回復

\begin{tabular}{|c|c|c|c|c|c|c|}
\hline 症 & 例 & 令 & 別 & 初診までの期間 & EcochG 施行時期 & EcochG 所見 \\
\hline \multirow[t]{2}{*}{7} & & \multirow[t]{2}{*}{12} & \multirow[t]{2}{*}{ 우 } & \multirow[t]{2}{*}{2} & & $\begin{array}{l}\text { AP low } \\
\mathrm{L}: 2.20 \mathrm{msec}\end{array}$ \\
\hline & & & & & 25 & $\mathrm{~L}: 1.80 \mathrm{msec}$ \\
\hline \multirow[t]{2}{*}{8} & & \multirow[t]{2}{*}{65} & \multirow[t]{2}{*}{$\hat{\delta}$} & \multirow[t]{2}{*}{7} & 13 & $\begin{array}{l}\text { AP low } \\
\text {-SP } \\
\mathrm{L}: 2.00 \mathrm{msec}\end{array}$ \\
\hline & & & & & 45 & $\mathrm{~L}: 1.95 \mathrm{msec}$ \\
\hline \multirow[t]{2}{*}{9} & & \multirow[t]{2}{*}{17} & \multirow[t]{2}{*}{ 今 } & \multirow[t]{2}{*}{2} & & $\begin{array}{l}\text { AP low } \\
\mathrm{L}: 2.25 \mathrm{msec}\end{array}$ \\
\hline & & & & & 34 & $\mathrm{~L}: 2.30 \mathrm{msec}$ \\
\hline \multirow[t]{2}{*}{10} & & \multirow[t]{2}{*}{45} & \multirow[t]{2}{*}{ 우 } & \multirow[t]{2}{*}{4} & & $\begin{array}{l}\text { AP low } \\
\text { L SP } \\
\mathrm{L}: 1.42 \mathrm{msec}\end{array}$ \\
\hline & & & & & 28 & $\mathrm{~L}: 1.40 \mathrm{msec}$ \\
\hline \multirow[t]{2}{*}{11} & & \multirow[t]{2}{*}{20} & \multirow[t]{2}{*}{$\hat{\sigma}$} & \multirow[t]{2}{*}{6} & & $\begin{array}{l}\text { AP low } \\
-\mathrm{SP} \\
\mathrm{L}: 2.50 \mathrm{msec}\end{array}$ \\
\hline & & & & & 30 & $\mathrm{~L}: 2.30 \mathrm{msec}$ \\
\hline \multirow[t]{2}{*}{12} & & \multirow[t]{2}{*}{43} & \multirow[t]{2}{*}{ 㑒 } & \multirow[t]{2}{*}{7} & & $\begin{array}{l}\mathrm{AP} \text { low } \\
\mathrm{L}: 2.70 \mathrm{msec}\end{array}$ \\
\hline & & & & & 38 & $\mathrm{~L}: 2.50 \mathrm{~ms} ə \mathrm{c}$ \\
\hline \multirow[t]{2}{*}{13} & & \multirow[t]{2}{*}{44} & \multirow[t]{2}{*}{$\hat{\delta}$} & \multirow[t]{2}{*}{3} & 4 & $\begin{array}{l}\text { AP low } \\
\text { L }: 2.00 \mathrm{msec}\end{array}$ \\
\hline & & & & & 40 & $\mathrm{~L}: 2.05 \mathrm{msec}$ \\
\hline \multirow[t]{2}{*}{14} & & \multirow[t]{2}{*}{45} & \multirow[t]{2}{*}{ 우 } & \multirow[t]{2}{*}{2} & 5 & $\begin{array}{l}\text { AP middle } \\
\mathrm{L}: 1.60 \mathrm{msec}\end{array}$ \\
\hline & & & & & 28 & $\mathrm{~L}: 1.55 \mathrm{msec}$ \\
\hline \multirow[t]{2}{*}{15} & & \multirow[t]{2}{*}{55} & \multirow[t]{2}{*}{$\hat{o}$} & \multirow[t]{2}{*}{2} & & $\begin{array}{l}\text { AP middle } \\
-\mathrm{SP} \\
\mathrm{L}: 1.50 \mathrm{msec}\end{array}$ \\
\hline & & & & & 35 & $\mathrm{~L}: 1.52 \mathrm{msec}$ \\
\hline 16 & & 62 & $\hat{\delta}$ & 2 & 2 & $\begin{array}{l}\text { AP low } \\
\text { L }: 2.20 \mathrm{msec}\end{array}$ \\
\hline
\end{tabular}

なお，10例全例に，いずれかの項目の平衡機能 検査で異常所見を認めている.

回復例は 6 例ある。乙のうち, A P $\left(\mathrm{N}_{1}\right)$ 無 反応之認められる屯のが 2 例あり, この 2 例之 も平衡機能検査で, 視標追跡眼運動検査は saccadic movement を示し, 温度眼振検查で両
側反忍低下を示した。すなわた，中枢性病変の 合併が疑われた。 また，他の 1 例では, APhigh amplitude であり, - S Pの分離も良好で あり, 潜時は $85 \mathrm{dBHL}$ にたいして $1.6 \mathrm{msec}$ と 正常範囲内にあった。乙の症例での平衡機能検 査成績は正常であった。ただし, 聴力の回復は 
c ）回復症例

\begin{tabular}{|c|c|c|c|c|c|c|}
\hline 症 & 例 & 年 令 & 性 別 & 初診までの期間 & EcochG 施行時 & EcochG 所見 \\
\hline 17 & & 48 & $\hat{o}$ & 3 & $\begin{array}{c}4 \\
40\end{array}$ & $\begin{array}{l}\mathrm{AP}(?) \\
\mathrm{AP}(?)\end{array}$ \\
\hline 18 & & 30 & $\hat{o}$ & 3 & $\begin{array}{l}3 \\
20\end{array}$ & $\begin{array}{l}\mathrm{AP} \quad \text { high } \\
\text { L }: 1.60 \mathrm{msec} \\
\mathrm{L}: 1.50 \mathrm{msec}\end{array}$ \\
\hline 19 & & 30 & $\hat{o}$ & 6 & $\begin{array}{l}6 \\
38\end{array}$ & $\begin{array}{l}\text { AP low } \\
\mathrm{L}: 2.50 \mathrm{msec} \\
\mathrm{L}: 2.45 \mathrm{msec}\end{array}$ \\
\hline 20 & & 28 & 우 & 3 & $\begin{array}{l}3 \\
40\end{array}$ & $\begin{array}{l}\text { AP middle } \\
\text { - SP } \\
\mathrm{L}: 1.82 \mathrm{msec} \\
\mathrm{L}: 1.80 \mathrm{msec}\end{array}$ \\
\hline 21 & & 占 & & 2 & $\begin{array}{r}5 \\
35\end{array}$ & $\begin{array}{l}\mathrm{AP}(?) \\
\mathrm{AP}(?)\end{array}$ \\
\hline 22 & & 41 & $\hat{o}$ & 7 & $\begin{array}{l}7 \\
50\end{array}$ & $\begin{array}{l}\text { AP low } \\
\text { L }: 2.35 \mathrm{msec} \\
\mathrm{L}: 2.40 \mathrm{msec}\end{array}$ \\
\hline
\end{tabular}

不変症例

\begin{tabular}{|c|c|c|c|c|c|c|}
\hline & 年 & 令 & 別 & 初診までの期間 & EcochG 施行時期 & EcochG 所見 \\
\hline 23 & & & 우 & 2 & $\begin{array}{l}12 \\
32\end{array}$ & $\begin{array}{l}\mathrm{AP}(?) \\
\mathrm{L}: 2.62 \mathrm{msec}\end{array}$ \\
\hline
\end{tabular}

治癒には至らなかった。

不変例は以下に紹介するような特異な経過を たどった。

以下各群の代表例をあげてその経過を申し述 べたい.

1）治癒症例

a ) 症例 2

59 才 女性 左側突発 性難聴（図 3 ）

発症 2 日目に受診. 初診時聴力は水平型の高 度感音性難聴を示している。発症後 7 日目に蝸 電図検査を施行. A P $\left(\mathrm{N}_{1}\right)$ の振幅は刺激強度

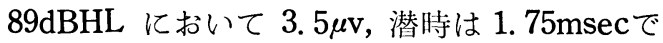
あり, 軽度の延長がみられた。 入出力曲線は Steep Slope で蛤電図上のリクルートメント現
象を認めた。一S Pの分離は良好である，発症 後 8 日目に行った平衡機能検査では異常所見を 認めなかった。発症後21日目に聴力は完全治癒 の状態となった，発症後22日目の蝸電図では刺 激強度 $85 \mathrm{dBHL}$ での A P $\left(\mathrm{N}_{1}\right)$ の潜時は 1.6 msec で短縮を認めた。 また，入出力曲線では L-response curve を認めるようになった。但 し, Steep Slope な入出力曲線には有意の変化 を示していない.

b ) 症例 3

43才 女性 右側突発 性難聴（図 4 ）

発症 3 日目に受診。初診時聴力は水平型の高 度難聴であった。発症 3 日目に蝸電図検査を行 うと, A P $\left(\mathrm{N}_{1}\right)$ は刺激強度 $85 \mathrm{ddHL}$ におい 

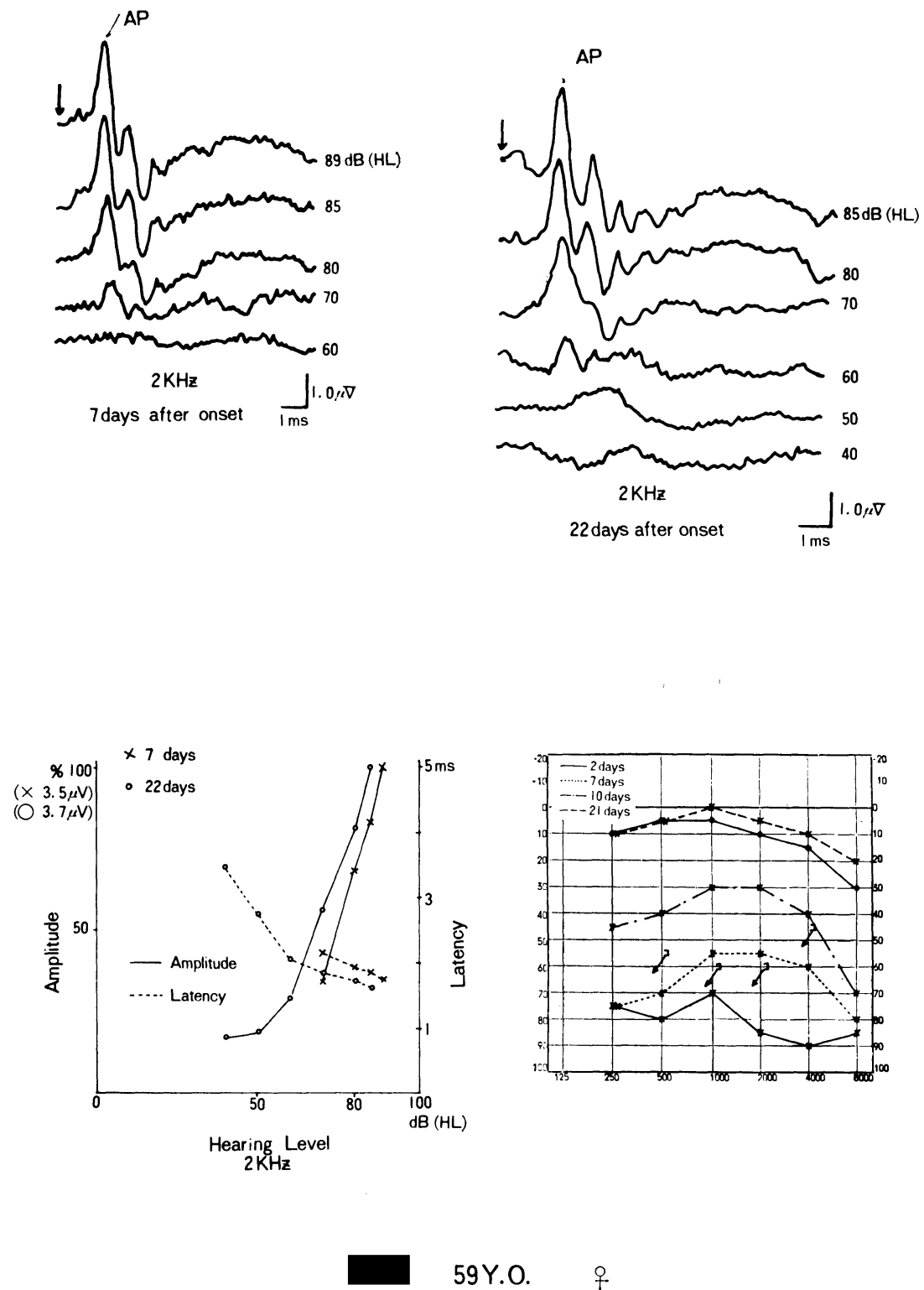

図 3 症例 2 (治癒例) 左側突発性難聴

発症 7 日目および22日目の蝸電図所見, 純音聴力の変動を示す. 治癒後の A P 潜時は短縮を認め, L-response curve を認める.

て振幅 $5.3 \mu \mathrm{v}$, 潜時 $1.35 \mathrm{msec}$ であった。また - S Pを認めた. 入出力曲線は Steep Slope であったが，L-response curve まで認められ た。発症後 7 日目には, 難聴は回復傾向を示し たが，この際行った蝸電図検查では，85dBHL

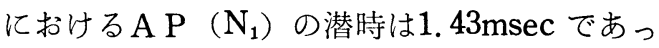
た. この值は初回検査時のそれより延長してい た。但し，健側耳での $85 \mathrm{dBHL}$ に対する潜時 は1. $45 \mathrm{msec}$ であった。なお，発症後 7 日目に 行った平衡機能検査には異常所見はない。この 

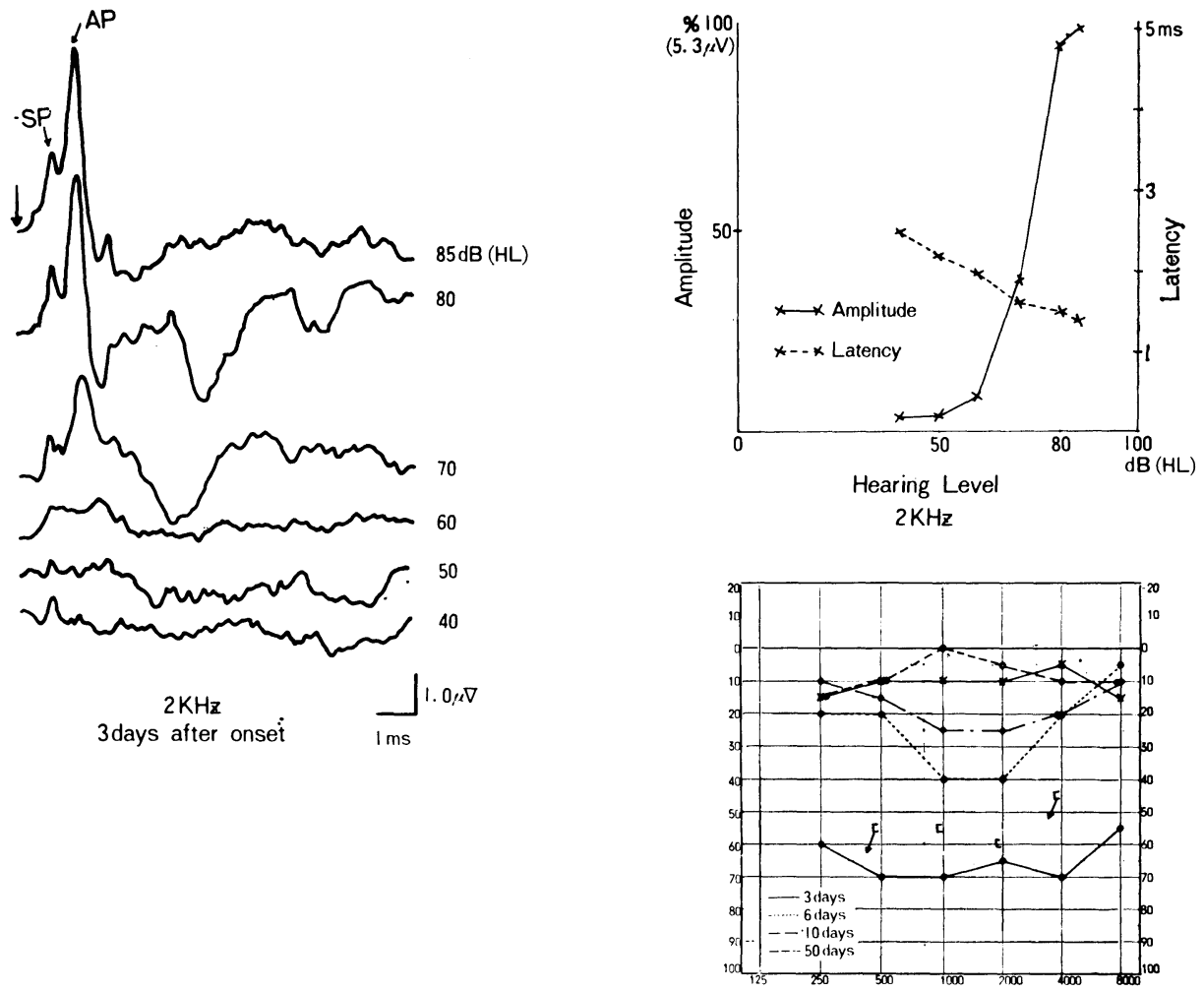

43Y.O. 우

図 4 症例 3 (治癒例) 右側突発性難聴 初譶時の蝸電図所見, 入出力曲線および純音聴力を示す. 初診時すでに L-response curve を認める.

症例の難聴は発病後50日で完全に消失し，汇常 化した.

2 ）著明回復例

a ) 症例 7 性難聴（図 5 ）

発症 2 日目に受診. この症例は難聴の他にフ ラフラ感と耳鳴を訴えていた。初診時に行った 気導骨導検査では高音急墜型の感音性難聴を示 し, 蝸電図検查では刺激強度 $89 \mathrm{dBHL} に お け$ る A P $\left(\mathrm{N}_{1}\right)$ の潜時は $2.2 \mathrm{msec}$ で延長傾向を 示し, 振幅は $1.3 \mu \mathrm{v}$ で low amplitude であっ た。さらに， $2 \mathrm{KHz}$ における蝸電図上の域值は 70dBHLであり；純音オーディオグラムの域值 $35 \mathrm{~dB}$ まで求めることはできなかった。発症 7
日目に行った平衡機能検査では，患側向きへの 自発眼振があり, 温度眼振検查で両側の反応低 下が認められた。発症11日目には，0.25，0.5, ， $2 \mathrm{KHz}$ では聴力の著明な改善をみたが, $4 \mathrm{KHz}$, $8 \mathrm{KHz}$ では中等度の難聴を残した。発症18日目 には自発眼振が消失した。発症25日目に行った 蝸電図検査では, A P $\left(\mathrm{N}_{1}\right)$ の潜時は $1.80 \mathrm{msec}$ と短縮を示した。

b) 症例 8

65才 男性 左側突発 性難聴（図 6 ）

発作性に眩暈, 嘔吐, 耳鳴, 難聴を来す。内 科を受診し入院加療を受ける。発症 7 日目に耳 鼻科受診. 初診時の純音聴力検査では高度の感 音性難聴を認めた。この症例には軽度の糖尿病 

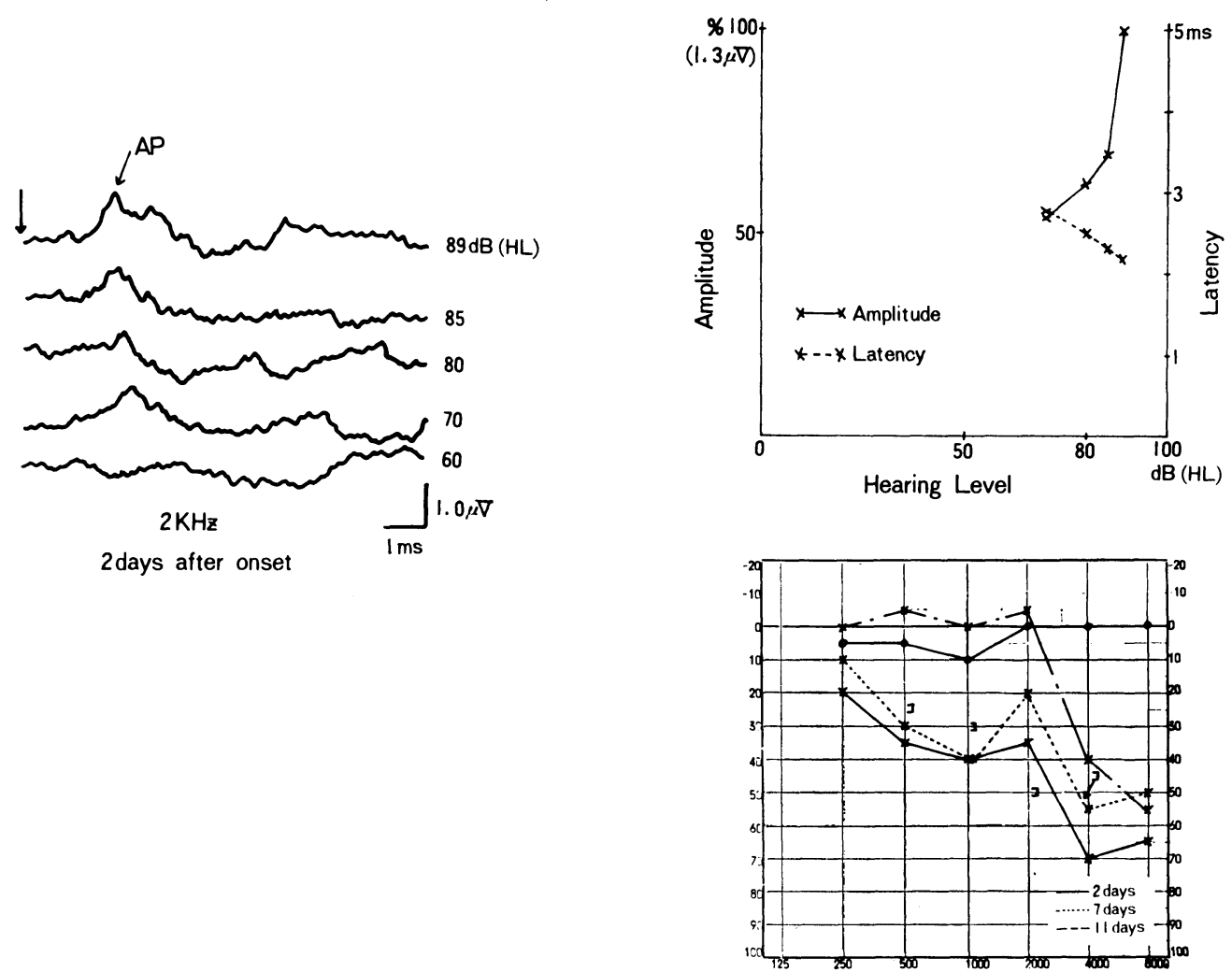

12Y.O. 우

図5 症例 7 (著明回復例) 左側突発性難聴

初診時蝸電図所見, 入出力曲線および純音聴力の変動を示す. A P は low amplitude であり, 潜時も延長している.

と高血圧が伴っている. 発症 8 日目に行った 平衡機能検査では注視方向性眼振や視運動性眼 振の解発抑制などの異常所見があり, 中枢性病 変が疑われた。但し，CT検査などでは異常所 見はみあたらなかった。発症13日目に行った蝸 電図検查では, 刺激強度 $85 \mathrm{dBHL}$ に打ける A P

$\left(\mathrm{N}_{1}\right)$ の潜時は $2.0 \mathrm{msec}$ であり延長傾向を示 し, 振幅は low amplitudeであった. 発症 20 日目には注視方向性眼振は右注視時にのみ認め られるようになった。この眼振は発症40日目に は消失したが, 耳鳴, 耳閉塞感が残存した。発 症45日目に行った蝸電図検查では, A P $\left(\mathrm{N}_{1}\right)$ の潜時は1.95msecであり, 振幅も low amplitude であり, 有意の変化を認めなかった.
3 ) 回復例

\section{症例 18}

$30 才$ 男性 右側突発性難 聴（図 7 ）

発症 3 日目に受診. 初診時の純音聴力検査は 感音性難聴を示し, その聴力像は高度の低音障 害型を示した。発症 3 日目の蝸電図検査では, 刺激強度 $85 \mathrm{dBHL}$ における $\mathrm{AP}\left(\mathrm{N}_{1}\right)$ の潜時は $1.60 \mathrm{msec}$, 振幅は $7.0 \mu \mathrm{v}$ で high amplitude で ある. 以上の所見から聴力の回復が期待された. しかし, 発症20日目に行った純音聴力検査では 平均 $15 \mathrm{~dB}$ の聴力の改善しか認められなかっ た. 同時に行った蝸電図検査では 85dBHL に たいし, A P $\left(\mathrm{N}_{1}\right)$ の潜時は $1.50 \mathrm{msec}$ と短縮 傾向を示し, 入出力曲線では L-response cu- 

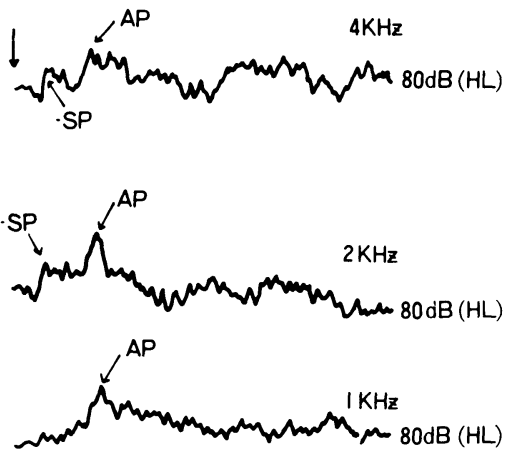

13 days after onset \rfloor$_{\mathrm{Ims}} 0.5 \mu \nabla$

W65.o. $\quad$ o

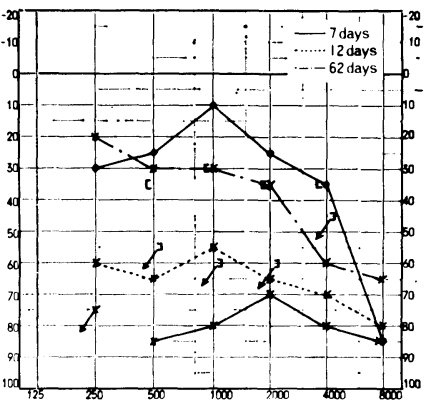

Equilibrium Test

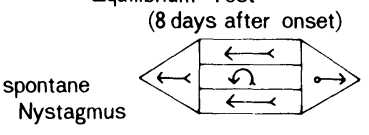

Fall tendency impossible

Step. impossible

Caloric $\quad \ell-\mathrm{cp}$

Positional Nystagmus

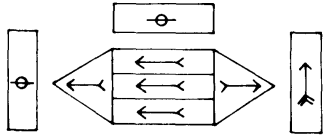

O.K.N. depressed

E.T.T. n. p.

図 6 症例 8 (著明回復例) 左側突発性難聴

発症13日目の蝸電図所見, 純音聴力の変動および発症 8 日目の平衡機能検 査成績を示す. A P 潜時は延長し, low amplitude である.

rve まで認められ，一S P は増大を示した。な お, 本例では平衡機能検査で異常所見は認めて いない，ちなみに，発症20日目に行った Bekesy の自記オーディオメトリーでは Type I であり，また $4 \mathrm{KHz}$ での SISI test は右側 100 \%であった。すなわち本例の難聴は内耳性を示 していた。

\section{4 ）不変例}

症例23

35才 女性 左側突発性難 聴 (図 8 )

発症 2 日目に来院. 眩暈は訴えていない. 純 音聴力検査で高音急丞型の難聴を認めた. 発症 2 日目に行った平衡機能検査では温度眼振検査 で左側 C P 型, 立ち直り検査で転倒傾向を認め
た. 発症 4 日目，患者は強い回転性の眩暈を訴 える. 発症11日目の純音聴力検査で左耳は壟と なり, 平衡機能検查では方向不定の自発眼振が 認められる。また, 足踏検査は実施不能, 視標 追跡眼運動検査では眼球運動は saccadic movement を示した。発症12日目に行った蝸電図 検査では, A P $\left(\mathrm{N}_{1}\right)$, S P ともに無反応であっ た。しかし，それ以後徐々に低音部の聴力は回 復の兆しがみられた。発症32日目に行った蝸電 図検査で初めてA P $\left(\mathrm{N}_{1}\right)$ を認めるようになっ た。なお， C T検査であ異常所見はなかった。 また，同時に行ったその他の全身的な諸検查で も異常所見を認めていない, 本症例では, 同じ 性格の発作が 2 回相ついで左耳におてり，ての 

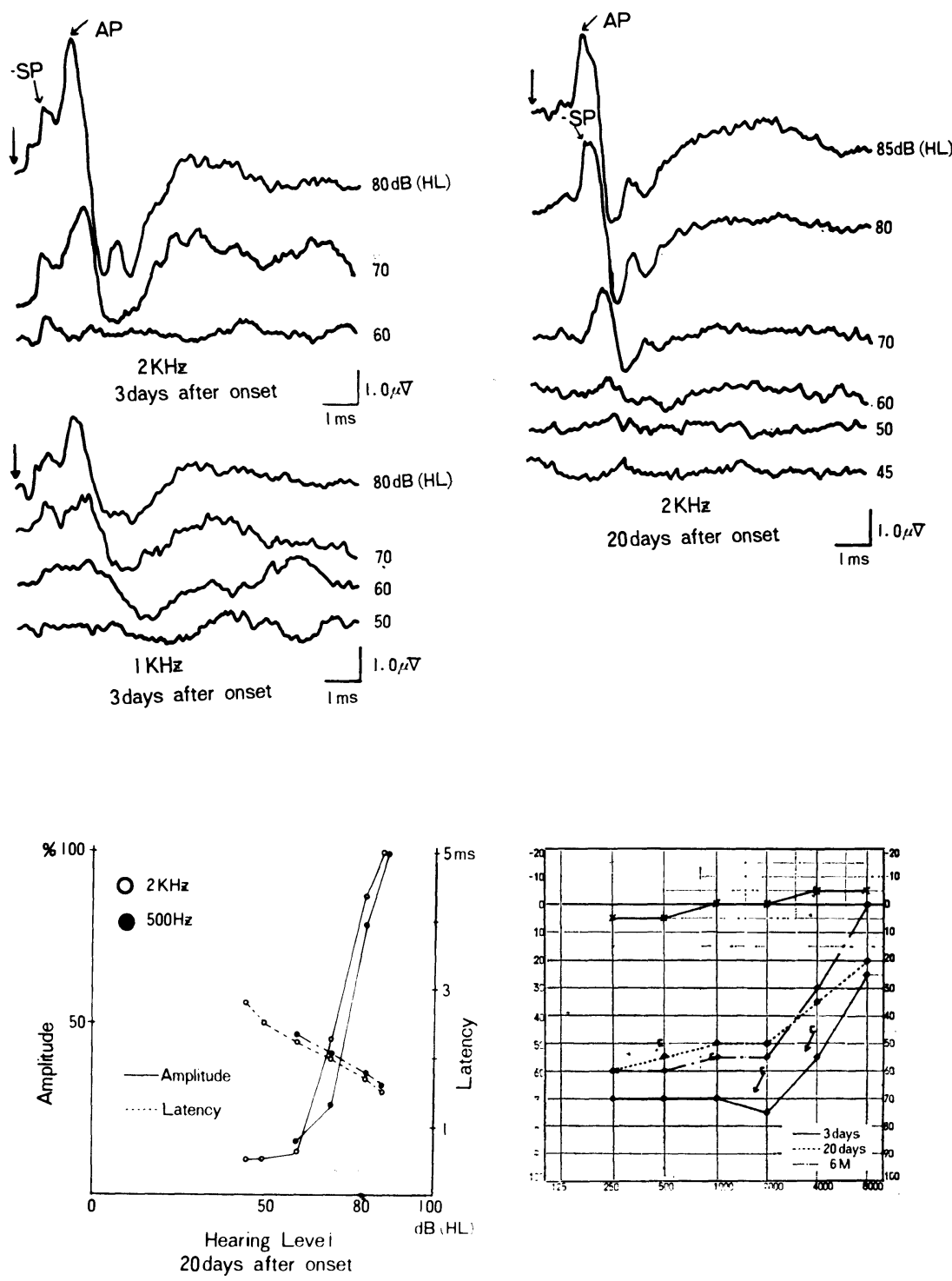

図 7 症例18（回復例）右側突発性難聴

初診時および 20 日目の蝸電図所見, 20 日目の入出力曲線および純音聴力の 変動を示す. A Pは high amplitude である.

耳に高度の聴力低下がもたらされたものか，あ るいは発症 4 日目の左耳の難聴は初回のそれと

\section{$\mathrm{V}$ 考}

1 ）平衡機能検査成績は予後判定に資しうる 加
は異った機序によるものと理解すべきなのか, なお不明の点を残している。

\section{按}

突発性難聴のある群に, 眩暈が伴われること が報告されているが，乙の疾患の予後と平衡機 

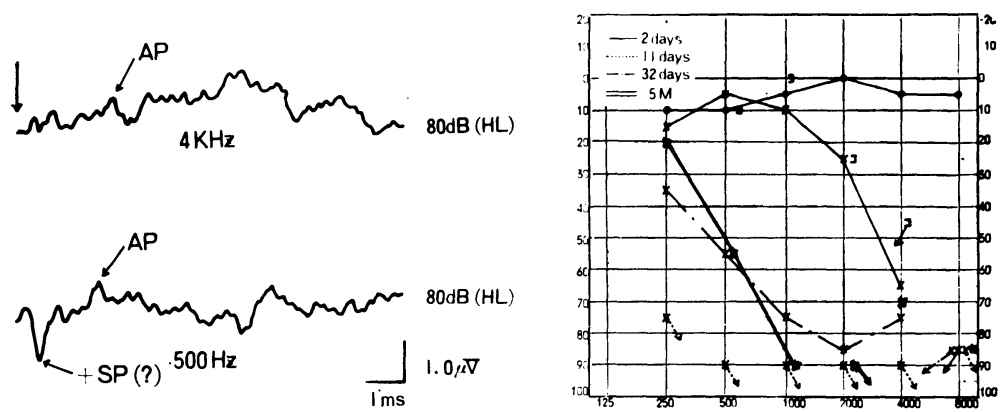

32 days after onset

2 day after onset

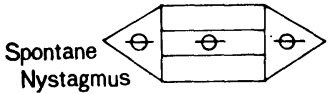

Fall

tendency inconstant

Step.

Caloric

O.K.N.

E.T.T. n. p.

$\ell-c p$

n.p.

n.p.
II days

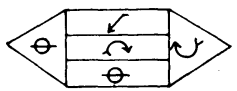

inconstant

impossible

$\boldsymbol{\ell}-\mathrm{cp}$

n.p.

slight saccade
32 days

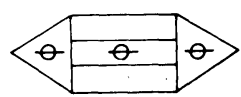

to $r$

to $r$

$\ell-c p$

n. p.

n. p.

n. p.
Positional

Nystagmus

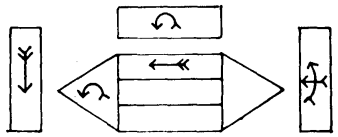

235Y.O. 우

図 8 症例23 (不变例) 左側突発性難聴

発症32日目の螖電図所見, 純音聴力の変動および平衡機能検査成績の推移を示す.

能検査成績との関連を報告した文献は予想外に 少い. とくに，今回の我々の報告のように，発 症後早期（発症後おそくとも 2 週間以内）に聴 力と平衡機能の両検査を行い, 難聴の予後判定 に関して, 平衡機能検査成績が役立ちうるか否 かを究明したものは，我々の知るかぎりほとん
どない，発症早期に両者を比較したという点に 固執しない場合，この問題に関連したものにつ いて述べると，次のようなものがある．すなわ ち, 生駒等 ${ }^{2)}$ の報告では, この疾患の聴力の予 後に関して, 眩量を伴う群と, 伴わない群とで は，有意の差がないと述べている．同じような 
意見が原田 ${ }^{3)}$ とより報告され，前庭機能の異常 の有無は予後判定の材料とはならないとしてい る。乙れにたいし，高橋等4)は，E NG検査を 暗所開眼下に行う場合, 眼振を認めるものは聴 力に関して予後が悪いてとを指摘している。ま た, Svane-Knudsen ${ }^{5)}$ む, 突発性難聴例の自 発眼振と聴力損失の相関を調査し，予後に関し て両者の関連性を認めている。

我々の今回の報告では, 平衡機能検査のどの 項目が聴力の予後に関して有意の相関を示すか を明らかにしてはいない。しかし，今回の我々 の成績よりすると, 聴力が治癒の状態にまで改 善するものでは，発症早期に行った平衡機能検 査で異常を示したものは有意に少い。例えば， 平衡機能検査で正常所見を示した16例のうち 12 例に打いて，聴力は治癒の状態を示すようにな った。乙れにたいし，平衡機能検査で異常所胃 を示した27例中，聴力が治癒の状態にまで改善 したものは，わずかに 1 例であった．以上のこ とより, 突発性難聴症例で, その聴力が治癒の 状態にまで回復するか否かを判定する際, 平衡 機能検査成績は有力な指針たりうるととがわか る.

しかし, その他の聴力の変動型と平衡機能検 查成績との間には上記のような相関は認められ ない，前庭機能異常が存しても，必ずしも聴力 の改善がえられないということはない，従って この問題の将来の検討は, いずれの平衡機能検 查項目に異常がある場合, 聴力回復を著しく妨 げるか，また幾つ以上の項目で異常があると聴 力回復が思わしくないかなど，よりきめ細かな 検討を必要とする. 今回は症例数がなお不充分 であり，てれらの検討を将来のものとして保留 せざるをえなかった。

2 ) 蝸電図検査成績は予後判定に資しうるか 蝸電図法による突発性難聴の予後判定に関す る系統的な研究報告はいまだ少い。神崎等6) は, 発症後15日目附近で蝸電図上に, L-response が出現したものは予後良好なものが多いよ 指摘している. 西田等 ${ }^{11}$ は Dominant-SP, AP high response を示すむのを予後良好型, Decreased AP, high response, AP low response, + S P, AP·SP no response を予後不 良型とし，予後の判定を行っている。しかし， 両者とも記録法として鼓室内誘導法を用いてお り，健側耳の記録を併せて行うこと，および反 復検査には困難なところがある。今回我々は外 耳道誘導を用い，健側耳の記録，反復検査を行 い, それらを比較検討して, 突発性難聴の予後 判定の可能性を検討した。

さて, 治癒症例では, 患側耳の蝸電図の A P $\left(\mathrm{N}_{1}\right)$ 振幅は健側耳のそれと同程度のものであ り，かつその潜時はほぼ正常範囲内であった。 このことは，乙れらの例では有毛細胞や聴神経 には器質的障害がなかったととを示唆してい る.すなわち, これらの例での聴力損失は, 聴 覚中枢路, 聴神経レベル，内リンパ腔内のいず れかのレベルでの可逆的変化，すなわち physiological block の状態が形成されたてとによ ると推定されよう。 Yoshie ${ }^{7)}$ によると，L-response は外有毛細胞および I 型ニューロンの, H-response は内有毛細胞㧍よび!型ニューロ ンの反応を各々示すという。 今回我々が報告し た治癒症例では 6 例中 3 例は発症後早期に Lresponse まで認められている。このことは， てれらの例での内耳有毛細胞におてっていた障 害が軽度でありかつ可逆的であり，検査時には すでに physiological block の状態が消夫し ていたものと理解される.

また，治癒症例のうち 3 例では治癒した時点 でA P $\left(\mathrm{N}_{1}\right)$ 潜時が短縮している。乙ては発症 侍一過性に生じた内耳の可逆的病変による内耳 感賞細胞の hyporeactivity を示唆するあので ある。乙れに対し, AP $\left(\mathrm{N}_{1}\right)$ の潜時が, 治癒 した時点でかえって延長している症例がある. このことは前者とは対照的に, 内耳病変により 蝸牛神経終末あるいは感覚細胞が刺激にたいし て hyperreactivity な状態にあったととを示唆 するむのである。このように，内耳活動性にた いする physiological blockにたいして内耳感 
覚細胞の示す態度は必ずしあ一様ではなく， あ るいは hyporeactivityをあるいは hyperreactivity を示すととが示唆されたととは貴重 である。

さて, 治癒症例と相似する蝸電図所見があっ ても著明な回復にまでも至らなかった症例があ る. この所見は A P 潜時や振幅のみで聴力の予 後判定を行うことの困難さを示している．ちな みに, この症例では-S P / A P の価が高く, メニエル病の聴電図之類似の所見 ${ }^{8)}$ を認めてい る. しかし, 前庭機能に有意の変化なく, かつ 低音障害型の聴力像を示しているが，乙れは Williams $^{9)}$ のいう endolymphatic hydrops without vertigo に相当するむのと考えられ る.

著明回復例では, 大多数例で A P $\left(\mathrm{N}_{1}\right)$ が low amplitude であり, 潜時は $2.0 \mathrm{msec}$ 以上 に延長している。 また，一SPが認められても low amplitude であり, このととは, 内耳有 毛細胞の障害を示唆する所見である。ただし， 本群に属する症例は純音オーディオグラムに て，高音部に聴力損失を残し障害が固定する場 合が多い。とのことは, 内耳有毛細胞の障害の 出現はそれ自体に一次的に成立したものではな く，むしろその他の病変が易障害性の高い基底
回転の毛細胞に作用し，そこに不可逆的変化を 及ぼしたものとも考えられ，今後の詳細な検討 が必要と考える．乙れらの症例では平衡機能検 查で全例に異常所見を認めている，従って，そ の主たる機序が何であるかは不明としてあ，治 癒症例に較べ, 内耳有毛細胞の障害の程度が強 く，より不可逆的状態にあったととは想定して もよいと思われる。

平衡機能検査成績より中枢性障害が疑われた 症例があるが，中島等 ${ }^{10)}$ の報告よりビールスの 関与が疑われる. とくに，回復例，不変例でみ られた A P 無反応の症例では, 蝸電図上にも後 蝸牛性障害の存在が示唆されているので, 上記 の考えを否定できない。

以上を要約すると, A P $\left(\mathrm{N}_{1}\right)$ が high amplitude で潜時の延長を認めない症例では，治 癒に至る公算が大きい。とれにたいし，A P， S Pが low amplitude で, A P $\left(\mathrm{N}_{1}\right)$ 潜時が 延長を示す症例では, 高音部に聴力損失を残 し，障害が固定する傾向が認められる。また， A P $\left(\mathrm{N}_{1}\right)$ 無反応の症例では聴力の回復は芳し くなく，高度の難聴を残し障害が固定する傾向 が認められる．これらの所見は，発症早期の蝸 電図検査は突発性難聴の予後判定に有用性のあ るととを物語っている。

\section{VI ま と め}

突発性難聴43症例を対象として, 発症早期（2 週間以内）に平衡機能検査および蝸電図検査を施 行し，ての疾患の予後判定に果す両検查の役割を検討した．得られた成績は次の通りである.

(1)治癒症例では AP high amplitude であり, 一 S P の分離む良好であった。潜時もほぼ正常範 囲内にあった。また，平衡機能検査でも，1例を除き，全例異常所見を認めなかった．

(2)著明回復例では AP low amplitude であり, - S P b low amplitude, 潜時も延長している 症例が多かった。また，16例中13例に平衡機能検査で異常所見を認めた.

(3)回復例, 不変例には A P 無反応の症例があり, 平衡機能検査成績とも併せ, 中枢性障害が疑わ れた。

以上の成績より, 突発性難聴の発症早期に, 平衡機能検査および蝸電図検査を行うことは, その 予後判定に有用性があると結論した.

稿を終るに臨み，桧学教授の御校閲を感謝いたします，尚，本論文の要旨は昭和54 年 6 月 3 日 日耳鼻第 5 回中 国地方部会連合会で口演した。 


\section{参考文 献}

1) 西田裕明, 他：蝸電図による突発性難聴の予後判 定. 日耳鼻 $79: 151 \sim 162,1976$.

2 ）生駒尚秋, 他：神経耳科学的立場から見た突発性 難聴之前庭神経炎. 耳鼻と臨床 $18: 401 \sim 405$, 1972.

3) 原田好雄 : 突発性難聴の治療と予後. Audiology 13: 185 190, 1970.

4) 高橋正紘, 他: 突発性難聴の予後と平衡機能検査 所見. 耳鼻臨床 $67: 541 \sim 555,1974$.

5 ) Svane-Knudsen, V. : Sudden "spontaneous" lesion of aural function. Acta otolaryng. 47 : 270 282, 1957.

6 ) 神崎仁, 他 : 突発性難聴新鮮例の聴力回復過程と 蝸電図所見. 耳鼻臨床 $68: 639 \sim 646,1975$.
7 ) Yoshie, N.: Diagnostic significans of the electrocochleogram in clinical audiometry. Audiology $12: 504 \sim 539,1973$.

8 ）井上靖二, 他 : $x$ 二エル病の蝸電図. 日耳鼻 79 : 747 760, 1976.

$9)$ Williams, H. L. : Endolymphatic hydrops without vertigo. Arch. otolaryng $51: 557 \sim 581$, 1950.

10）中島成人, 他: 突発性難聴の 3 症例について一特 にVirus との関係. 日耳鼻 $79: 142 \sim 150$, 1976.

原稿到着 : 昭和 55 年 10 月 31 日
別刷請求先 $:$ 岩永迪孝
T530 大阪市北区神山町 $13-3$
北野病院耳鼻咽䐅科 